\title{
The reliability and efficiency of power companies
}

\author{
I.G. Akhmetova ${ }^{1, *}$, and N.D. Chichirova ${ }^{2}$ \\ ${ }^{1}$ Economics and organization department, Kazan State Power Engineering University, Kazan, Russia \\ ${ }^{2}$ Thermal power stations department, Kazan State Power Engineering University, Kazan, Russia
}

\begin{abstract}
One of the key indicators of heat supply organizations is the reliability of energy facilities. The index of reliability of heat supply organization is of interest to potential investors, to assess the risks of investing projects. We propose a method of determining the reliability of heat supply organizations with the use of SAW (simple additive weighting method). We are developing a versatile program and the analysis of heat supply organizations on the example of the Republic of Tatarstan. This criterion is of significant interest for potential investors to assess the risks of investing projects. All values for the calculation of the reliability of heat supply organization founded and are publicly available. The method of determining the reliability of heat supply organizations with the use of SAW. Developed a versatile program allows you to analyze the performance reliability of any heat supply organizations.
\end{abstract}

\section{Introduction}

The current state of the economy and standard of living are largely determined by the presence of stockpiles of fuel and energy resources and their efficiency. For countries whose economies are based mainly on the import of energy resources, namely efficiency is one of the determining factors of competitive products.

In many countries, legal frameworks allow to provide legitimacy for basic energy efficiency measures. This is particularly important in the cases where special tax incentives or subsidies have been established [17-20].

Among fifteen "old" Member States of the European Union (EU) in ten of them there are state subsidies for energy-saving measures and the conditions for obtaining grants established by law, as recorded in the judicial acts.

In some countries, the law on tax benefits (incentives) is legislated. If some business unit is using energy-saving equipment, or performs services relating to energy conservation, then a tax credit is provided for it. This Act applies in respect of individuals and small groups.

Some programs offer an option for companies: to pay tax on energy consumption or to make investments in activities that improve energy efficiency. Details of tax benefits have been judicially regulated [18].

\section{Research relevance}

The heat supply infrastructure in Russian Federation requires a systemic modernization. The loss in heat networks of the country reaches $20-30 \%$, which is almost four times higher than in Europe. In order to solve all this problems require significant resources are needed. It is estimated that underinvestment in the industry is almost three trillion rubles. The only way for the development of industry today is to attract private investment. This requires a transition to a modern market model, free of regulation and developing transparency for investors. In the case of successful attracting investments, fixed assets of companies operating in the energy market, as a matter of fact, undergo a substantial renovation and change.

Obtaining private investments and budgets is only possible on the basis of organizations investmentattractiveness and some potential reliability, which guarantees a return on investment. We have developed different methods for determining the reliability of the potential of foreign companies [17-20]. The analysis showed that at the present time, a single and internationally recognized procedure does not exist. In each country there is a specificity of the energy sector, which significantly affects the difference in determining the potential of reliability. At the same time the state of scientific developments in Russian Federation offers new mechanisms, criteria and methods in organizing of rating in the different sectors of economic activity [21].

Among other devices one of the most important tools of managing is assessment and monitoring of the performance of heat supplying companies. Currently, the problems of creating production and investment programs are of significant importance for planning of the industrial power complex organizing practices.

The fuel component in the tariff for electric power up to $80 \%$, indicating the fact that the scale of possible savings of resources and the absence of the possibility of self-financing investment projects in the Russian Federation's economy (Fig. 1).

The research intentions in this field has repeatedly been made in [2, 3], but a fully formed system of

Corresponding author: irina_akhmetova@mail.ru

(C) The Authors, published by EDP Sciences. This is an open access article distributed under the terms of the Creative Commons Attribution License 4.0 (http://creativecommons.org/licenses/by/4.0/). 
indicators characterizing the state of heat, is currently lacking.

Indicators of reliability established by federal law in Russia actually have been reduced to a single numerical value, which depends on the number of terminations of heating in connection with violations of the heating systems and the volume of the recovery of the resource for the relative year. This particular indicator is rather subjective and can vary over a wide range several years' periods. Using only the above-described indicator for an objective assessment of insufficient heat supply system reliability, but these figures may be used as an integrated component of the reliability index.

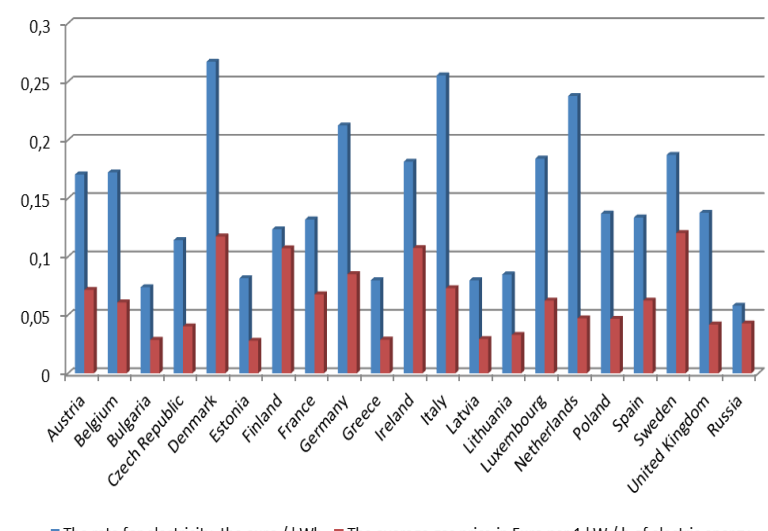

Fig. 1. The fuel component in the tariff for electric energy in different countries.

Methods of determining the integrated index should satisfy the following conditions:

- the full and objectively reflection of the reliability level of the heat supply system which is calculated;

- the information used to calculate the reliability index should be readily available - posted on the Internet in accordance with the disclosure standards.

\section{A new method for evaluating the reliability of the power company}

To assess the reliability of heat supply organizations are invited to the next set of indicators (Table 1).

During selection of these indicators the results of methodological developments in the field of formation of indicators system, which conduct independent analytical centers and individual researchers, was taken into account. The evaluation system is based on the construction of the comparative ratings of heat supply organizations. Rating is an assessment of the reliability, it is characterized by a numerical value and allows you to compare the organizations involved in one activity together.

In this paper we applied SAW [7] (the method of a simple additive weighting) - a method for determining the reliability of heat supply organizations.

SAW method can be considered reliable only when the consistency of expert opinion is sufficient. Statistically examining the information received from experts, should assess the coherence their opinions and establish the cause of inadequate information. When applying the method of paired comparisons consistency of expert opinion is not checked, it is proposed to use the expert method [15] and a method for checking the consistency of expert opinions proposed by L. Evlanov [16]. These methods are integrated in a single algorithm. Scheme SAW improved method is shown in Fig. 2.

Table 1. Indicators reliability of the heat supply organization.

\begin{tabular}{|c|c|c|}
\hline Indicator & Formula & Note \\
\hline $\begin{array}{l}\text { 1. Depreciation of } \\
\text { equipment of } \\
\text { thermal energy } \\
\text { sources }\end{array}$ & $\begin{array}{l}\text { Total wear thermal } \\
\text { energy sources for } \\
\text { the period / initial } \\
\text { cost of fixed assets }\end{array}$ & $\begin{array}{l}\text { Determined to } \\
\text { further decrease } \\
\text { the degree of } \\
\text { serviceability of } \\
\text { heat sources }\end{array}$ \\
\hline $\begin{array}{l}\text { 2. Deterioration of } \\
\text { heat networks }\end{array}$ & $\begin{array}{l}\text { Total wear of } \\
\text { heating networks } \\
\text { for the period / } \\
\text { initial cost of fixed } \\
\text { assets }\end{array}$ & $\begin{array}{l}\text { Determined to } \\
\text { further decrease } \\
\text { the degree of } \\
\text { serviceability of } \\
\text { heat networks }\end{array}$ \\
\hline $\begin{array}{l}\text { 3. Number of } \\
\text { stopping delivery } \\
\text { of thermal energy, } \\
\text { heat carrier as a } \\
\text { result of } \\
\text { technological } \\
\text { breakdowns in the } \\
\text { heating networks } \\
\text { in the } 1 \mathrm{~km}\end{array}$ & $\begin{array}{c}\text { Method of } \\
\text { calculation - the } \\
\text { decision № } 452\end{array}$ & $\begin{array}{l}\text { Describes the } \\
\text { actual level of } \\
\text { damage to the } \\
\text { thermal networks }\end{array}$ \\
\hline $\begin{array}{l}\text { 4. Number of } \\
\text { stopping delivery } \\
\text { of thermal energy, } \\
\text { heat carrier as a } \\
\text { result of } \\
\text { technological } \\
\text { breakdowns on } \\
\text { sources of heat for } \\
1 \text { GCal / h } \\
\text { installed capacity }\end{array}$ & $\begin{array}{c}\text { Method of } \\
\text { calculation - the } \\
\text { decision № } 452\end{array}$ & $\begin{array}{l}\text { Describes the } \\
\text { actual level of } \\
\text { damage to the } \\
\text { thermal energy } \\
\text { source }\end{array}$ \\
\hline $\begin{array}{l}\text { 5. Ratio costs } \\
\text { thermal energy } \\
\text { cost directed } \\
\text { on resource } \\
\text { recovery, renewal } \\
\text { of fixed assets }\end{array}$ & $\begin{array}{l}\text { Costs for } \\
\text { modernization, } \\
\text { reconstruction, } \\
\text { repair of fixed } \\
\text { assets / Cost of } \\
\text { thermal energy }\end{array}$ & $\begin{array}{l}\text { Allows us to } \\
\text { estimate } \\
\text { resources } \\
\text { devoted to } \\
\text { increase } \\
\text { reliability }\end{array}$ \\
\hline $\begin{array}{l}\text { 6. Coefficient of } \\
\text { renewal of fixed } \\
\text { assets }\end{array}$ & $\begin{array}{l}\text { Cost of fixed assets } \\
\text { entered in the } \\
\text { period / value of } \\
\text { fixed assets }\end{array}$ & $\begin{array}{l}\text { Shows which } \\
\text { part of the } \\
\text { existing at the } \\
\text { end of the } \\
\text { reporting period } \\
\text { of fixed assets } \\
\text { comprise new } \\
\text { fixed assets } \\
\end{array}$ \\
\hline $\begin{array}{l}\text { 7. Coefficient of } \\
\text { disposal of fixed } \\
\text { assets }\end{array}$ & $\begin{array}{l}\text { Cost of retired fixed } \\
\text { assets for the period } \\
\text { / value of fixed } \\
\text { assets }\end{array}$ & $\begin{array}{c}\text { Shows the } \\
\text { proportion of } \\
\text { core resources } \\
\text { available to the } \\
\text { beginning of the } \\
\text { reporting period, } \\
\text { dropped out } \\
\text { during the } \\
\text { reporting period } \\
\text { due to } \\
\text { dilapidation and } \\
\text { wear }\end{array}$ \\
\hline
\end{tabular}




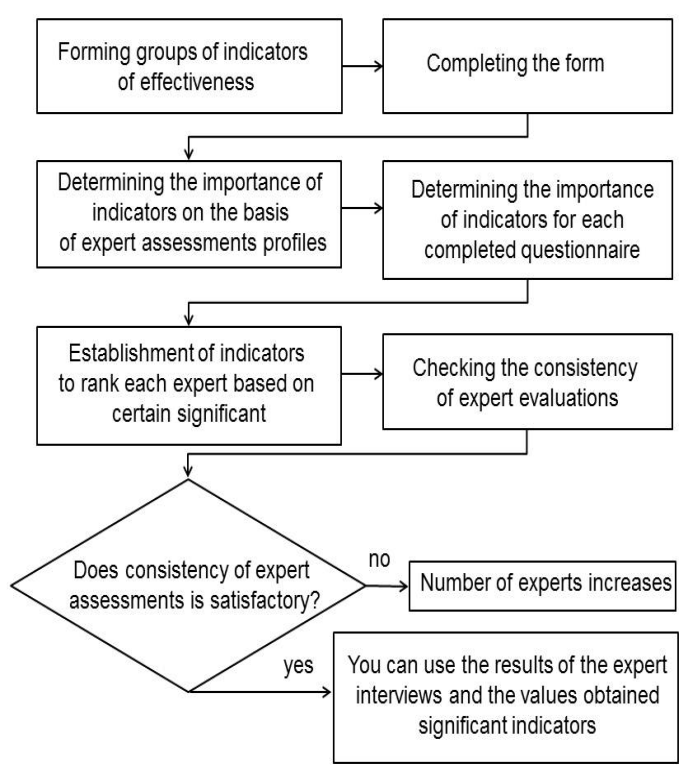

Fig. 2. The flowchart determining the significance.reliability indexes paired comparison method.

Then formed the ranks of indicators, and obtained $t_{j k}$ sets of values (Table 2).

Table 2. Determination of the reliability of heat supply organization.

\begin{tabular}{|c|c|c|c|c|}
\hline Expert & \multicolumn{4}{|c|}{ Reliability Index } \\
\hline$E_{1}$ & $t_{11}$ & & $\ldots$ & \\
\hline$E_{2}$ & $t_{12}$ & & $\ldots$ & \\
\hline$\ldots$ & $\ldots$ & $\ldots$ & $\ldots$ & $\ldots$ \\
\hline$E_{k}$ & $t_{1 r}$ & & $\ldots$ & \\
\hline $\begin{array}{c}\text { The } \\
\text { sum of } \\
\text { ranks }\end{array}$ & $\sum_{i=1}^{k} t_{1 k}$ & $\sum_{i=1}^{k} t_{2 k}$ & $\ldots$ & $\sum_{i=1}^{k} t_{n k}$ \\
\hline $\begin{array}{c}\text { Average } \\
\text { grade }\end{array}$ & $\overline{t_{1}}$ & $\overline{t_{2}}$ & $\ldots$ & $\overline{t_{n}}$ \\
\hline
\end{tabular}

A comparative analysis of indicators of reliability of the seven energy companies.

In accordance with the proposed method we investigated the rank of reliability organizations was determined (Fig. 3).

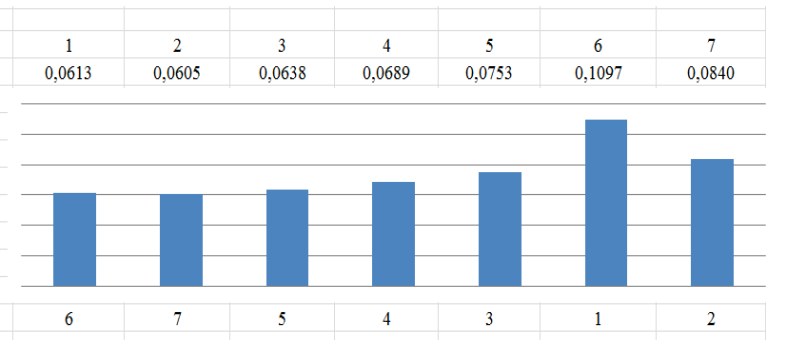

Fig. 3. Determination of the reliability of heat supply organizations rank.

Generalized values of heat supply organizations reliability indicators are shown in Fig. 4, which shows the place of each organization in comparison with the best analogues.

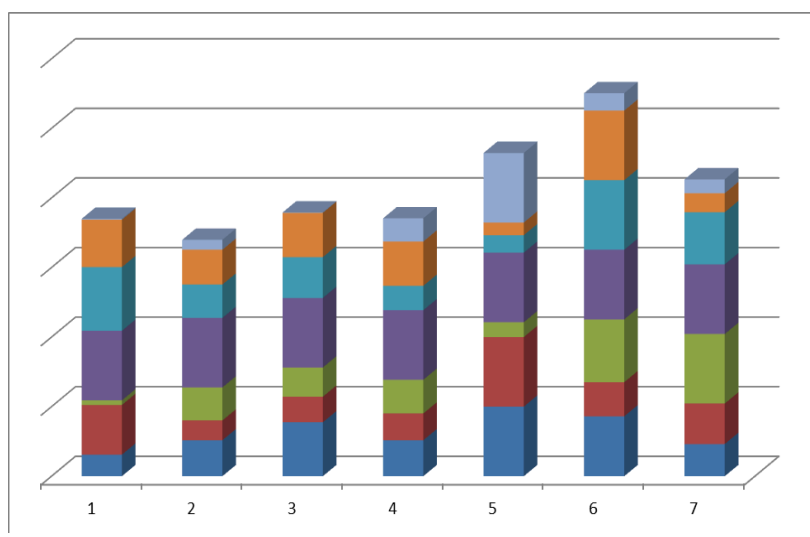

Fig. 4. Generalized values of reliability indicators heat supply organizations: Coefficient of disposal of fixed assets; Coefficient of renewal of fixed assets; Ratio costs thermal energy cost directed on resource recovery, renewal of fixed assets; Number of stopping delivery of thermal energy, heat carrier as a result of technological breakdowns on sources of heat for $1 \mathrm{Gcal} / \mathrm{h}$ installed capacity; Number of stopping delivery of thermal energy, heat carrier as a result of technological breakdowns in the heating networks in the $1 \mathrm{~km}$; Deterioration of heat networks1. Depreciation of equipment of thermal energy sources; Depreciation of equipment of thermal energy sources.

\section{Conclusion}

Thus, we have clarified the definition of the reliability indicator. This criterion is of significant interest for potential investors to assess the risks of investing projects. All values for the calculation of the reliability of heat supply organization founded and are publicly available. The method of determining the reliability of heat supply organizations with the use of SAW (simple additive weighting method). Developed a versatile program allows you to analyze the performance reliability of any heat supply organizations.

\section{References}

1. E.Y. Sokolov, District heating and heat networks: the textbook (Publishing. House MPEI, Moscow, 2006)

2. The quality of the energy in the conditions of scientific and technological progress (Proceedings OIEI, Leningrad, 1975)

3. E.P. Kuznetsov, Heat energy efficiency technology, 2 (1996)

4. E.V. Sennova, S.N. Kiryuhin, S.A. Shimanskaya, News heating, 12(160) (2013)

5. A.I. Yufa, D.R. Nosulko, Complex optimization of heating (TECHNIK, Kiev, 1988)

6. A.A. Son of Jonah, The reliability of heat networks systems (Stroyizdat, Moscow, 1989)

7. S. Greco, B. Matarazzo, R. Slowinski, Operational Tools in the Management of Financial Risksyu, Dordrecht: Kluwer Academic Publishers, 121-136 (1998) 
8. D.H. Safiullin, Management strategic potential reliability of power grid companies as a business structures (Moscow, 2013)

9. K.J. Arrow, Econometrica, 213-243 (1949)

10. C.L. Hwang, K. Yoon, Multiple Attribute Decision Making Methods and Applications, A State of the Art Survey (Springer Verlag, Berlin, Heidelberg, New York, 1981)

11. E. Zavadskas, A. Kaklauskas, Proc. Integrating Technology \& Human Decisions-Global Bridges into the 21st Century, Athens, Greece, 2051-2053 (1999)

12. A. Kaklauskas, N. Kvederyte, E.K. Zavadskas, Multiple Criteria Analysis of a Buildings Life Cycle (Vilnius, Technika, 2001)

13. S. Jakucionis, L. Ustinovicius, STATYBA (Civil Engineering), VI, 6, 469-475 (2000)

14. T.A. Saaty, Journal of Mathematical Psychology, 15, 3, 234-281 (1977)

15. E.K. Zavadskas, Comprehensive evaluation and selection of resource-saving solutions in the Banking (Vilnius, Mokslas, 1987)
16. L. Evlanov, Theory and practice of decisionmaking (Economics, Moscow, 1984)

17. Combined Heat and Power: A Resource Guide for State Energy Officials. www. naseo.org/ data/sites/1/ documents/ publications/ CHP-forState-Energy-Officials.pdf.

18. Fabio Correa Leite, DecioCicone Jr., Luiz Claudio Ribeiro Galvao, Miguel Edgar Morales, Open Journal of Energy Efficiency, 2, 22-28 (2013)

19. Peng Wang, Proc. Sch. of Municipal \& Environ. Eng., Harbin Inst. of Technol, 233-236 (2009)

20. Luca Podofillini, Bruno Sudret, Bozidar Stojadinovic, Enrico Zio, Wolfgang Kröger, Safety and Reliability of Complex Engineered Systems (ESREL, CRC Press, 2015)

21. E.G. Gachot, M.V. Stepanova, Energy policy, 3, 59-66 (2015)

22. The adoption of "Expertchoice" Decision Support System. http://www.expertchoice.com/. 